\title{
PECULIARITIES AND STAGES OF HIGHER SCHOOL TEACHER FORMATION
}

\author{
PECULIARIDADES E ESTÁGIOS DA FORMAÇÃO DE PROFESSORES DO ENSINO \\ SUPERIOR
}

\author{
PECULIARIDADES Y ETAPAS DE LA FORMACIÓN DE PROFESORES DE \\ ESCUELA SUPERIOR
}

\author{
Irina V. TENENTYEVA ${ }^{1}$ \\ Anastasia V. FAKHRUTDINOVA ${ }^{2}$ \\ Maria Y. KARELINA ${ }^{3}$ \\ Ekaterina A. KARELINA ${ }^{4}$ \\ Igor V. GAIDAMASHKO
}

\begin{abstract}
The article discusses the issues of improving the professionalism of a higher education teacher; it also describes activities designed to improve the quality of the educational process, and the role of the leadership of an educational organization in the formation of a teacher. Initial knowledge, skills, abilities and qualities are formed by the teacher in the process of his or her professional activity and during the part of his or her life that precedes work in an educational institution. Professional qualities actively develop only with the beginning of teaching activities. The development of the initiative and the creative search in the work of a teacher is of particular relevance, because improving the quality of formation cannot be achieved by simply increasing the working time of teachers and the study time of students. New teaching methods and new techniques for developing the students' creative activity are needed, which would allow them to achieve high results. Moreover, the state's policy should include real material and moral support for a creatively working teacher of an educational institution, including teachers at higher schools.
\end{abstract}

KEYWORDS: Students. University. Pedagogical skills. Improvement of professional competence. Advanced training of teaching staff.

RESUMO: O artigo discute as questões de melhoria do profissionalismo de um professor de educação superior; também descreve atividades destinadas a melhorar a qualidade do processo educacional, e o papel da liderança de uma organização educacional na formação

${ }^{1}$ Kazan Federal University (KPFU), Kazan - Russia. Professor of the Department of International Relations, World Politics and Diplomacy, Institute of International Relations. Doctor of Sciences (Pedagogics). ORCID: https://orcid.org/0000-0002-7072-6822.E-mail: iterenteva49@mail.ru

2 Kazan Federal University (KPFU), Kazan - Russia. Professor of the Department of Foreign Languages, Institute of International Relatons. ORCID: https://orcid.org/0000-0001-7872-7507. E-mail: avfach@mail.ru

${ }^{3}$ Moscow Automobile and Road State Technical University (MADI), Moscow - Russia. Professor. Doctor of Pedagogical Sciences and Doctor of Technical Sciences. ORCID: https://orcid.org/0000-0003-0335-7550. Email: karelinamu@mail.ru

4 Moscow State University of Technology (STANKIN), Moscow - Russia. Assistant Professor of the Department of Foreign Languages. Candidate of Economic Sciences. ORCID: https://orcid.org/0000-0002-84024215. E-mail: opferpriesterin@mail.ru

5 Moscow State Regional University (MGOU), Moscow - Russia. Professor of the Department of Labor Psychology and Organizational Psychology. Doctor of psychology. ORCID: https://orcid.org/0000-0001-51460064. E-mail: giv414@gmaik.com

RPGE- Revista on line de Política e Gestão Educacional, Araraquara, v. 25, n. esp. 1, p. 538-546, mar. $2021 . \quad$ e-ISSN:1519-9029 DOI: https://doi.org/10.22633/rpge.v25iesp.1.14994 
de um professor. Os conhecimentos, capacidades, habilidades e qualidades iniciais são formados pelo professor no processo de sua atividade profissional e durante a parte de sua vida que precede o trabalho em uma instituição de ensino. As qualidades profissionais se desenvolvem ativamente somente com o início das atividades de ensino. O desenvolvimento da iniciativa e da busca criativa no trabalho de um professor é de particular relevância, pois a melhoria da qualidade da formação não pode ser alcançada simplesmente aumentando o tempo de trabalho dos professores e o tempo de estudo dos alunos. Novos métodos de ensino e novas técnicas, para desenvolver a atividade criativa dos estudantes, são necessárias, o que lhes permitiria alcançar resultados mais elevados. Além disso, a politica do Estado deve incluir apoio material e moral real para um professor criativamente ativo de uma instituição de ensino, incluindo professores de escolas superiores.

PALAVRAS-CHAVE: Estudantes. Universidade. Habilidades pedagógicas. Aprimoramento da competência profissional. Treinamento avançado dos docentes.

RESUMEN: El artículo analiza las cuestiones relacionadas con la mejora de la profesionalidad de un profesor de educación superior; también describe actividades diseñadas para mejorar la calidad del proceso educativo y el papel del liderazgo de una organización educativa en la formación de un docente. Los conocimientos, destrezas, habilidades y cualidades iniciales son formados por el docente en el proceso de su actividad profesional y durante la parte de su vida que precede al trabajo en una institución educativa. Las cualidades profesionales se desarrollan activamente solo con el comienzo de las actividades docentes. El desarrollo de la iniciativa y la búsqueda creativa en el trabajo de un docente es de especial relevancia, porque no se puede mejorar la calidad de la formación simplemente aumentando el tiempo de trabajo de los docentes y el tiempo de estudio de los estudiantes. Se necesitan nuevos métodos de enseñanza y nuevas técnicas para desarrollar la actividad creativa de los estudiantes, que les permitan alcanzar altos resultados. Además, la política del estado debe incluir un apoyo material y moral real para un maestro de una institución educativa que trabaje creativamente, incluidos los maestros de las escuelas superiores.

PALABRAS CLAVE: Estudiantes. Universidad. Habilidades pedagógicas. Mejora de la competencia profesional. Formación avanzada del profesorado.

\section{Introduction}

The social and political importance of the teacher has been well understood at all times. The most far-sighted statesmen have always sought to use teachers for their political aims. For example, Julius Caesar gave all teachers of the Roman Empire citizenship rights. A Prussian teacher, as Bismarck noted, defeated France in the war of 1870, and American politicians used to point directly at the fact that the launch of the first satellite of the Earth had been ensured by successes made possible thanks to the Soviet school. In Japan, respect for the teacher is elevated to the rank of cult. 
The teacher of an educational organization of higher education is the backbone of the learning process, the carrier of the content of education and upbringing, and also the organizer of all cognitive activities, the level and quality of which depends on the level of scientific, methodological and professional training of the teaching staff (KHAIRUTDINOV et al., 2019). The personality of the teacher, his or her pedagogical and scientific weight, personal charm, knowledge and culture, desire for creativity etc. are also important (FAKHRUTDINOVA; KADYJROVA; MUSINA, 2017). At the same time, the culture of education and upbringing by itself, if lacking purposeful, systematic and integrated work, is impossible. "Just as no one can give another that which he himself does not have," noted the German teacher A. Disterweg, "so one who himself is not developed and educated cannot develop or educate others. In fact, he is only able to educate as long as he works on his own upbringing and education” (DIESTERWEG, 1820; DIESTERWEG, 1857).

Consequently, pedagogical activity (actions of a teacher), pedagogical communication (climate and atmosphere of a teacher's work) and personality (value orientations, ideals, internal meanings of his or her work) are three sides of a teacher's work, which are always interconnected and united by common strategic tasks of teaching and education arising from the social order of society.

\section{Methods}

The study used both traditional pedagogical and psychological methods (the study of experience, primary sources, conversations, ascertaining experiment, creative experiment), as well as sociological and mathematical methods. Among sociological methods, the sociometric method has been used (the method of studying group differentiation and the method of generalizing independent characteristics by K. Platonov). As to the mathematical methods of pedagogical research, ranking and modeling methods were mainly used.

\section{Results and discussion}

Three types of teachers are determined by the intensity of development of pedagogical abilities and mastery of skill.

The first type includes teachers who, from the first year of independent work, confidently and quickly go to master pedagogical skills. They are characterized by a pronounced pedagogical orientation - the desire to be not just a teacher, but a master teacher. 
This type is characterized by moral and psychological preparedness for pedagogical work and a high sense of responsibility for its results.

The second type includes teachers who master their skills slowly, which is associated with insufficient self-discipline, as well as poor theoretical and methodological readiness. An uncritical attitude to one's own experience or conflicting relationships with colleagues may limit the process of mastering certain pedagogical skills.

The third type is characterized by inability to develop their abilities. Teachers of this type had practically no experience working with students before starting independent activities, they are weak organizers, and they are also not prepared for work in a theoretical sense, therefore, they lack interest in work, their vocabulary is poor, speech is inexpressive, and their behavior is constrained.

Initial knowledge, skills, abilities and qualities are formed in a teacher not only in the process of his or her professional activity, but also throughout his or her life, which precedes work in an educational institution. Professional qualities actively develop only with the beginning of the teaching activities.

A modern young teacher should join the process of implementing a competency-based approach in vocational education as soon as possible and be involved in the process of modernization of education (VERBITSKY, 2009; BELENTSOV; FAHRUTDINOVA; GREVTSEVA, 2019).

Since one of the sustainable trends in the further development of education in the world is the continued growth of academic mobility, the number of students studying abroad has reached 3.7 million by 2010 and will reach 7.2 million by 2020 . In the Russian Federation, there is a slight increase in the number of foreign citizens receiving education in the country (MOISEEV et al., 2019).

Students from China, Vietnam, Malaysia, Myanmar, Mongolia and other countries study at Moscow Automobile and Road State Technical University (MADI).

While working at a university, a young teacher should be ready not only to teach Russian students, but also to take into account the historical, socio-political, economic and cultural characteristics of countries delegating their citizens to receive higher education in Russia. The main aspects of the formation of a productive dyad "teacher-foreign student" have been analyzed by Prof. Rementsov (2011).

An important part of professional excellence is a high level of education, although education alone is not enough, experience is also important (REMENTSOV 2011; BELENTSOV; FAHRUTDINOVA; GREVTSEVA, 2019). 
The relationship between professional skill and experience is not straightforward, because one does not automatically lead to another (NIKOLAEVNA; VICTOROVNA; FARIDOVNA, 2017).As practice shows, an increase in skill due to experience only takes the first 5-7 years, and then, if the teacher does not improve his qualifications, does not study or work on himself, experience does not play any role.

From the foregoing, we can conclude that the main age when a teacher is formed as a master is young years.

Young teachers go through three stages in their formation: adaptation, active mastery of professional experience and maturity; the pace of transition from one stage to another is different. Beginning teachers do not all become masters at the same time. Important reasons for a low pace are the weak activity of the teacher himself, a low level of pedagogical and methodological preparedness, insufficiently formed abilities for pedagogical activity, an unfavorable situation at the department or insufficient help from more experienced colleagues.

The apex of pedagogical excellence is pedagogical creativity (KHAIRUTDINOV et al., 2019; BELENTSOV; FAHRUTDINOVA; GREVTSEVA, 2019). Pedagogical creativity in the broadest sense is the discovery by a teacher of varied non-standard ways of solving pedagogical problems (these methods are known and described, however, the teacher subjectively opens them for himself). Pedagogical creativity in a narrower sense means innovation. First of all, this is the creation of new original finds, or holistic approaches that change the usual view of the phenomenon and rebuild public experience. This is a special type of non-standard thinking, including, first of all, a new concept and methods for detecting problems of problematic reality with their subsequent original solution.

The development of the initiative and the creative search in a teacher's work is of particular relevance, because improving the quality of training cannot be achieved by simply increasing the working time of teachers and the study time of students. New teaching methods as well as new techniques for developing the students' creative activity are needed, which would allow to achieve high results (FAKHRUTDINOVA; KADYJROVA; MUSINA, 2017; MOISEEV et al., 2019). Moreover, the state's policy should imply different kinds of real material and moral support for a creatively working teacher of an educational institution, including teachers of higher school.

The process of improving the professional pedagogical activity of university teachers has its own specific features. Firstly, measures to improve it are organically included in the 
general system of advanced training of teachers and many of them are regulated as mandatory in policy documents.

Secondly, this process proceeds in the course of continuous direct practical activity of teachers. On the one hand, this limits the possibilities due to lack of time, but, on the other hand, it creates favorable conditions on the basis of constant pedagogical practice.

Thirdly, the process organically combines two levels of implementation: activities of the leadership of educational institutions and departments, as well as self-improvement of teachers in their field.

Fourthly, a specific result of improving the professional pedagogical activity of teachers of higher education organizations is to increase the professional qualifications and quality of teaching, which is achieved through positive changes in individual pedagogical techniques.

Fifthly, by its content and organization, the process contributes to the "pedagogization" of the life of an educational institution, as well as to the humanization and democratization of relations between teachers and students.

Let us dwell on the main problems of the teaching staff at technical universities, which were indicated by the Rector of the Moscow Automobile and Road State Technical University (MADI), Corresponding Member of the Russian Academy of Sciences Prikhodko (2014).

Firstly, this is the problem of the "gap" between generations. Due to their age, a significant part of higher education teachers, with rare exceptions, are not able to master innovative technologies, new techniques and the competency-based approach as a whole. So, in essence, there is no one to educate young teachers.

Secondly, a sharp change in the regulatory framework of higher education and insufficient time to adapt to new bachelor's and master's educational programs makes it rather difficult for even experienced teachers to get used to modern and rapidly changing conditions.

Thirdly, it is the destruction in a certain peropd of time of the system of further advanced training of teachers established in the USSR (PRIKHODKO, 2014).

Fortunately, the last circumstance, which is one of the main problems in training staff for technical universities, is not relevant for MADI.

Under the current conditions, when the Russian education system is in a state of deep reform, it is the MADI Institute of Continuing Education that is also involved in the advanced training of the University's teaching staff, along with programs aimed at working with staff of organizations in the real sector of the economy. 
Based on the experience of Sholokhov Moscow State University for Humanities regarding the implementation of the "Concept of modern humanitarian education at the university" (MOISEEV et al., 2019). the founder of the context-competency-based approach to the modernization of education. Verbitsky (2014), notes that ongoing continuing education courses for all university managers, teachers and key employees will contribute to the university entering the space of educational reform in a context-competency-based format.

\section{Summary}

Thus, ranking them by importance, we can identify the main ways of training young teachers who have the necessary tools and competencies to participate in the high-quality implementation of the educational process.

In our opinion, the main ways teachers can achieve professionalism in their work are:

- Refresher and further training courses for teachers

- A teacher's self-education

-Activities of the department to improve the level of the teacher's professionalism

- Work of the international department to familiarize teachers working with foreign students with the socio-cultural aspects that accompanied the student in his or her homeland.

The integration of these components is the basis for forming the competencies of a young teacher who would be able to implement the educational process in accordance with the requirements of higher education and the needs of society.

\section{Conclusions}

Peculiarities and stages of becoming a higher education teacher take place in universities of both engineering and socio-humanitarian profile. The mainstream of modern educational technologies in Russia is now the formation of a teacher with competency profiles in the field of pedagogy, scientific research and high communication abilities.

ACKNOWLEDGEMENTS: The work is performed according to the Russian Government Program of Competitive Growth of Kazan Federal University. 


\section{REFERENCES}

BELENTSOV, S. I; FAHRUTDINOVA, A. V; GREVTSEVA, G. Y. Free education: Fundamentals of humanistic pedagogics (on the example of activity of the German public figures of the second half of XIX - the beginning of the XX centuries of F. Gansberg, L. Gurlitt, G. Sharrelman). European Journal of Contemporary Education, v. 8, n. 1, p. 201207, 2019.

DIESTERWEG, F. A. W. Pädagogishces wollen und sollen. Berlin,1857.

DIESTERWEG, F. A. W. Ueber erziehung im allgemeinen und schul-erziehung im besonderen. 1820 .

FAKHRUTDINOVA, A. V.; KADYJROVA, L. H.; MUSINA, K. I. Artistic and aesthetic education of students by the means of the national arts and crafts: the Tatarstan republic experience. International E-Journal of Advances in Education, v. 3, n. 8, p. 268-273, 2017.

KARELINA, M. Y.; MOISEEV, V. V.; KARELINA, E. A.; KOMAROVA, O. A. The Priorities of Higher Education in Russia. Advances in Social Science, Education and Humanities Research, v. 322, p. 250-254, 2019.

KHAIRUTDINOV, R.; MUKHAMETZYANOVA, F.; FAKHRUTDINOVA, A.; PANCHENKO, O.; BOGOVAROVA, V. Forming readiness of master's degree students for scientific and research activity. ARPHA Proceedings, v. 1, p. 345, 2019.

MOISEEV, V. V.; KIROVA, I. V.; KOMAROVA, O. A.; KARELINA, M. Y. Organization of Research Work of Students in Russia. In: INTERNATIONAL SEMINAR ON EDUCATION RESEARCH AND SOCIAL SCIENCE, 2., 2019, Kuala Lumpur. Proceedings [...]. Kuala Lumpur, Malaysia: Atlantis Press, 2019.

MOISEEV, V. V.; GLAGOLEV, S. N.; KARELINA, E. A.; CHEREPNINA, T. Y. Actual Problems of Higher Education in Russia. Advances in Social Science, Education and Humanities Research, v. 322, p. 244-249, 2019.

NIKOLAEVNA, V. M.; VICTOROVNA, F. A.; FARIDOVNA, D. G; modern use of the pedagogical technology team-teaching in the training of teacher candidates. QuidInvestigacion Ciencia y Tecnologia, n. 28, p. 767-772, 2017.

PRIKHODKO, V. M. Prospects for the training of teachers of engineering disciplines in Russia. Center for Engineering Education MADI, Moscow, n. 16, p. 3-11, 2014.

REMENTSOV, A. N. Features of training foreign citizens from the main contingent-forming countries at the preparatory faculty of MADI. Bulletin of the Theory and Methodology of Vocational Education, n. 4, p. 24-28, 2011.

VERBITSKY, A. A. Context-competency-based approach to the modernization of education. Higher education in Russia, Moscow, n. 5, p. 32-37, 2010. 
VERBITSKY, A. A. Lecturer in the context of education reform. Center for Engineering Education MADI, Moscow, n. 16, p. 35-50, 2014.

VERBITSKY, A. A. Personal and competency-based approaches in education: problems of integration. Moscow: Logos, 2009. 336 p.

\section{How to reference this article}

TENENTYEVA, I. V.; FAKHRUTDINOVA, A. V.; KARELINA, M. Y.; KARELINA, E. A.; GAIDAMASHKO, I. V. Peculiarities and stages of higher school teacher formation. Revista on line de Política e Gestão Educacional, Araraquara, v. 25, n. esp. 1, p. 538-546, mar. 2021. e-ISSN:1519-9029. DOI: https://doi.org/10.22633/rpge.v25iesp.1.14994

Submitted: 06/11/2020

Required revisions: $18 / 01 / 2021$

Approved: $23 / 02 / 221$

Published: 01/03/2021 